\title{
Metabolic effects of a low-magnesium diet in pigs
}

\author{
BY P. J. NUORANNE \\ Department of Animal Hygiene, Veterinary College, \\ 00550 Helsinki 55, Finland \\ R. P. RAUNIO \\ Department of Biochemistry, University of Turku, \\ 20500 Turku 50, Finland \\ P. SAUKKO \\ Department of Forensic Medicine, University of Oulu, \\ 90220 Oulu 22, Finland \\ AND H. KARPPANEN \\ Department of Pharmacology, University of Helsinki, \\ 00170 Helsinki 17, Finland
}

\section{(Received 5 March 1979 - Accepted 17 December 1979)}

1. Pigs were fed on semi-purified food. The magnesium content of the experimental diet was $1 \cdot 0$ and that of the control diet $I .9 \mathrm{~g} / \mathrm{kg}$.

2. In the low-Mg group serum triglycerides and blood lactate values were increased and base excess and standard bicarbonate values were decreased, indicating metabolic acidosis.

3. A significant positive dependence was found between blood $\mathrm{pH}$ and serum $\mathrm{Mg}: \mathrm{Ca}$ value as well as between blood $\mathrm{pH}$ and serum $\mathrm{Mg}$, and also between body temperature and blood lactate values in the low-Mg group. None of these dependences was significant in the control group with magnesium acetate supplementation in the food.

4. No specific histopathological changes were found in heart, liver or kidney of the experimental animals.

5. The results indicate that an increase in serum triglycerides does not need to depend on the amount or quality of food fat.

6. The present study shows that, in pigs, a low-Mg diet may cause metabolic disturbances in instances when the food $\mathrm{Mg}$ content is distinctly higher than the normal values recommended by the (UK) Agricultural Research Council (1966) and (US) National Research Council (I968).

The two distinctive symptoms of magnesium deficiency across species are hyperirritability and metastatic calcifications (Jacobson et al. 1972). It is also known that $\mathrm{Mg}$ deficiency can cause many kinds of cardiovascular and gastrointestinal disorders (Szelényi, I973; Seelig \& Heggtveit, 1974).

According to the (UK) Agricultural Research Council (ARC; I966) and (US) National Research Council (NRC; 1968 ) approximately $0.4 \mathrm{~g} \mathrm{Mg} / \mathrm{kg}$ pig food is a sufficient amount to satisfy requirements. The $\mathrm{Mg}$ content of ordinary pig food is 4 - to 5-fold greater than this. On the basis of clinical experience of pigs it was proposed by Nuoranne (197I) that leg weakness and cannibalism, for example, could be successfully treated by means of abundant doses of magnesium oxide or sulphate.

Since 1972 all industrial pig foods in Finland have been supplemented by a considerable amount of $\mathrm{Mg}$. In 1974 and 1978 indirect evidence was presented by Nuoranne $(1974,1978 \mathrm{~b})$ which further suggested that this $\mathbf{M g}$ supplementation had exerted a favourable effect on many disorders like bruxism, splay leg, leg weakness, hepatosis dietetica, acute cardiac failure and anaemia. A great part of these disorders seemed to be functional failures of muscle tissue. 
Table I. The composition of the food by analysis

$\begin{array}{lc} & \mathbf{g} / \mathbf{k g} \\ \text { Dry matter } & 895 \\ \text { Crude protein (nitrogen } \times \text { 6.25) } & 190 \\ \text { Crude fibre } & 32 \\ \text { Crude fat } & 17 \\ \text { Ash } & 44 \\ \text { N-free extract } & 612 \\ \text { Calcium } & 8 \cdot 8 \\ \text { Phosphorus } & 5 \cdot 3 \\ \text { Magnesium } & 1 \cdot 0 \\ \text { Potassium } & 4 \cdot 1 \\ & \mathrm{mg} / \mathrm{kg} \\ \text { Copper } & 110 \\ \text { Zinc } & 213 \\ \text { Iron } & 365\end{array}$

On the basis of changes in enzyme activities in serum it has been found that pigs fed on an ordinary diet may suffer from $\mathrm{Mg}$ deficiency despite the fact that the food $\mathrm{Mg}$ content is distinctly higher than normal values recommended by ARC (1966) and NRC (I968) (Nuoranne, I978a).

In this study pigs were fed on a semi-purified diet with a low $\mathrm{Mg}$ content and an attempt was made to find out if this diet caused a state of $\mathrm{Mg}$ deficiency in the experimental pigs.

\section{EXPERIMENTAL}

\section{Animals, food and the course of the experiment}

The four experimental and the four control pigs originated from the same litter. On the basis of pre-experimental determinations, the experimental groups were made as equal as possible in terms of serum $\mathrm{Mg}$, body-weight and sex.

The experimental food consisted of $(\mathrm{g} / \mathrm{kg})$ white wheat flour 550 , barley flour 215 , oat flour 100 , dried blood 100 . It was supplemented by $(\mathrm{g} / \mathrm{kg})$ dicalcium phosphate 20 , limestone 6 , and the vitamin and mineral mixture (excluding $\mathrm{Mg}$ ) by which industrial pig foods are supplemented during preparation $\left(\mathrm{mg} / \mathrm{kg} \mathrm{NaCl} 3296.5, \mathrm{KJ}_{5}, \mathrm{CuO}_{120}\right.$, $\mathrm{CoSO}_{4} \cdot 7 \mathrm{H}_{2} \mathrm{O} 8, \mathrm{ZnO}{ }_{170}, \mathrm{FeSO}_{4} \cdot 7 \mathrm{H}_{2} \mathrm{O} 300, \mathrm{MnO}$ 100, sodium selenite $0 \cdot 2$, retinol $3000 \mu \mathrm{g} /$ $\mathrm{kg}$, ergocalciferol $50 \mu \mathrm{g} / \mathrm{kg}$ and $\alpha$-tocopherol $30 \mathrm{mg} / \mathrm{kg}$.

The food contents analysed are shown in Table $\mathrm{I}$. The calculated digestible protein content of the food was $164 \mathrm{~g} / \mathrm{kg}$. The food of the control group was daily supplemented with $8 \mathrm{~g}$ magnesium acetate $/ \mathrm{kg}$ food. The calculated $\mathrm{Mg}$ content in the food of the control group was thereby raised to $1 \cdot 9 \mathrm{~g} / \mathrm{kg}$.

The drinking-water of the pigs contained $5-6 \mathrm{mg} \mathrm{Mg} / 1$ and there was no straw in the pens. Consequently, the gain of $\mathrm{Mg}$ from sources other than food was minimized.

After weaning the experimental pigs were fed on an ordinary pig diet $(2 \cdot 1 \mathrm{~g} \mathrm{Mg} / \mathrm{kg})$. During the last week before the experiment pigs were stepwise accustomed to eat experimental food with $\mathrm{I} \cdot 9 \mathrm{~g} \mathrm{Mg} / \mathrm{kg}$.

At the beginning of the experiment the pigs were 7 weeks old. The average weight of the experimental pigs was $19.7 \mathrm{~kg}$ and that of control pigs $19.5 \mathrm{~kg}$. During the $6 \mathrm{I} \mathrm{d}$ experiment, the average gain of weight was $29.1 \mathrm{~kg}(477 \mathrm{~g} / \mathrm{d})$ in the experimental group and $30.7 \mathrm{~kg}$ $(503 \mathrm{~g} / \mathrm{d})$ in the control group.

On the experimental days $0,6,9,14,22,34,43$ and 6 I blood samples were taken from vena cava cranialis at 07.00 hours (before feeding). 


\section{Biochemical determinations}

Pyruvate and lactate were estimated from blood after perchloric acid precipitation using lactate dehydrogenase (EC I.I.I.27) as an assay enzyme (Czok \& Lamprecht, 1974; Gutman \& Wahlefeld, 1974). Enzymic serum triglyceride assay after enzymic hydrolysis was employed for neutral fat determination (Wahlefeld, 1974). All three assays were performed using assay kits obtained from Boehringer Mannheim GmbH, Germany, and the samples were stored at $-20^{\circ}$ before assay.

For the determination of acid-base balance, blood was taken from the ear veins into heparinized capillary tubes (Radiometer D 55I/I0/80; Radiometer, Copenhagen) and the acid-base measurements were made using an Astrup Radiometer Design 22 in a hospital laboratory.

Alanine aminotransferase ( $E C$ 2.6. I . 2 ; ALAT), aspartate aminotransferase ( $E C$ 2 .6 . I . I ; ASAT), lactate dehydrogenase and D-glutamyltransferase $(E C$ 2.3.2.1; $\gamma$-GT) activities, glucose, creatinine and total protein in serum were determined by routine clinical methods using a Gilford 3500 computer-directed analyser (Gilford Instrument Laboratories Inc., Oberlin, Ohio). $\mathrm{Mg}$ and calcium levels in serum were determined by means of atomic absorption spectroscopy, serum inorganic phosphorus using Hitachi-Perkin-Elmer I 39 UVVIS spectrophotometer, and serum sodium using Corning flame photometer 430.

\section{Histochemical and enzyme-histochemical methods}

When the pigs were slaughtered, tissue samples were taken from heart, liver and kidney for light microscopy. Transmural samples of myocardium were cut from the anterior wall of each ventricle and the interventricular septum. Each sample was divided into two parts. Half was fixed in buffered formalin (100 ml/l) for $48 \mathrm{~h}$, embedded in paraffin, cut at $5 \mu \mathrm{m}$ and stained with haematoxylin-eosin. The other half was frozen in liquid nitrogen and $10 \mu \mathrm{m}$ sections were cut on a cryostat and stained for $\beta$-hydroxybutyrate dehydrogenase (EC I . I . I . 30; Barka \& Anderson, 1965).

\section{Statistical methods and reference values}

Two-way analysis of variance including repeated measures (split-plot design) was used for testing the differences between the groups, and linear regression analysis for testing the dependences between various measurements within the groups. In addition to serum $\mathrm{Mg}, \mathrm{Ca}$, the molar $\mathrm{Mg}: \mathrm{Ca}$ value or lactate, time $(T, \mathrm{~d})$ was used as an independent variable in the regression equations.

The reference values of serum triglycerides, lactate and pyruvate are the average values of eight samples which were taken from randomly selected pigs aged 2 months and fed on an ordinary pig diet with $2 \cdot 1 \mathrm{~g} \mathrm{Mg} / \mathrm{kg}$ food. For the reference values for acid-base measurements and serum $\mathrm{Mg}$ and $\mathrm{Mg}: \mathrm{Ca}$ values two litters each with six pigs were grown from the age of 2 months to 3-3.5 months and blood sampling was carried out every 2 weeks. A total of forty-two samples were examined. Reference values (mean $\pm \mathrm{SE}$ ) were: serum Mg 0.88 $\pm 0.01 \mathrm{mM}$, serum Mg:Ca $0.333 \pm 0.005$, triglycerides $504 \pm \mathrm{I} 2 \mathrm{mg} / 1$, pyruvate $0.18 \pm 0.01 \mathrm{mM}$, lactate $4.4 \pm 0.1 \mathrm{mM}$, base excess $0.3 \pm 0.4 \mathrm{mM}$, standard bicarbonate $24.6 \pm$ $0.4 \mathrm{~mm}$, actual pH 7.31 $\pm 0.0 \mathrm{I}$, partial pressure of carbon dioxide $5^{8} \pm 0.9 \mathrm{mmHg}$.

\section{RESULTS}

In the low-Mg group a statistically significant increase in serum triglycerides and lactate values, and a decrease in base excess and standard bicarbonate values were found (twoway analysis of variance, split-plot design; Table 2). The changes in serum triglycerides, 


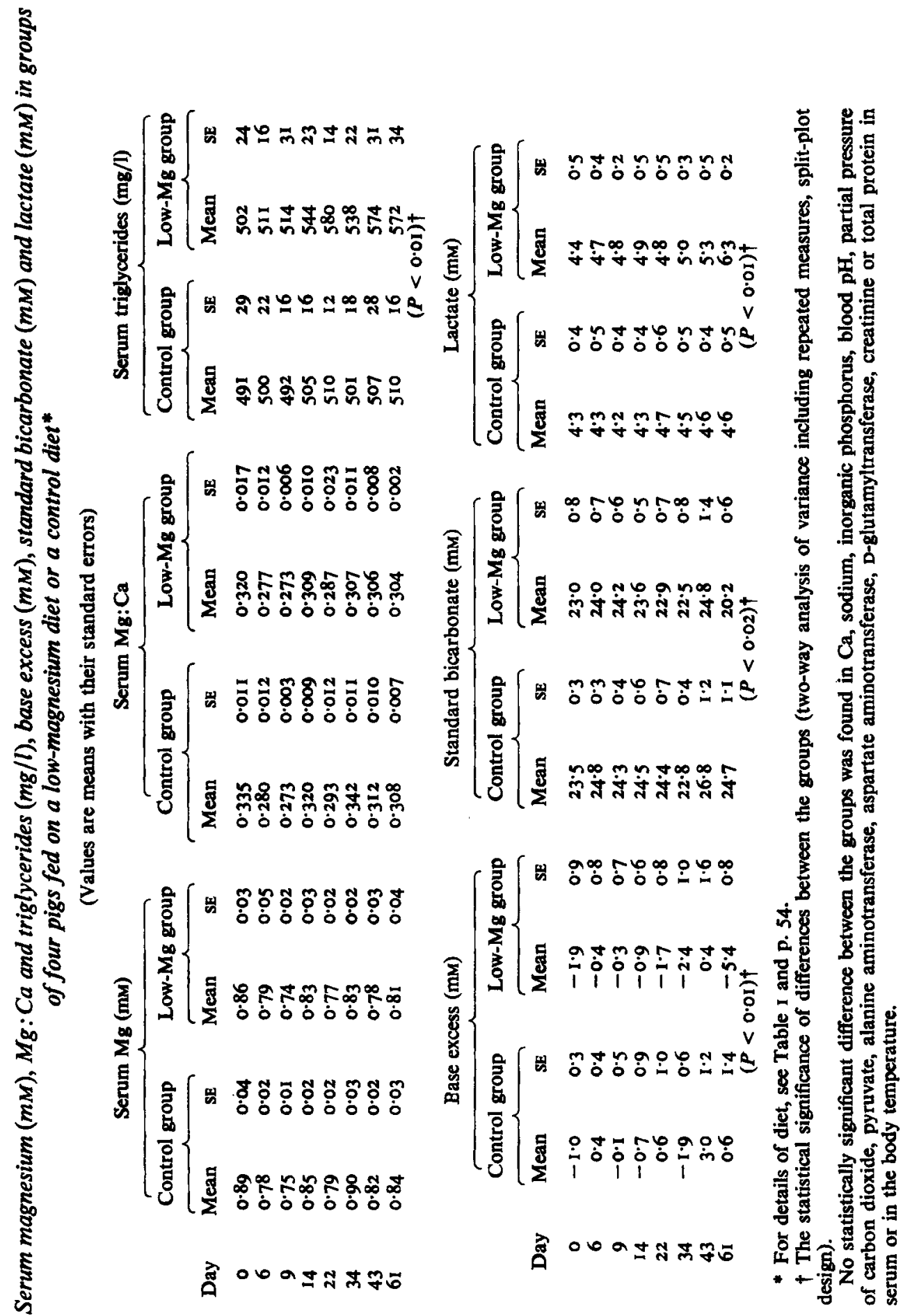




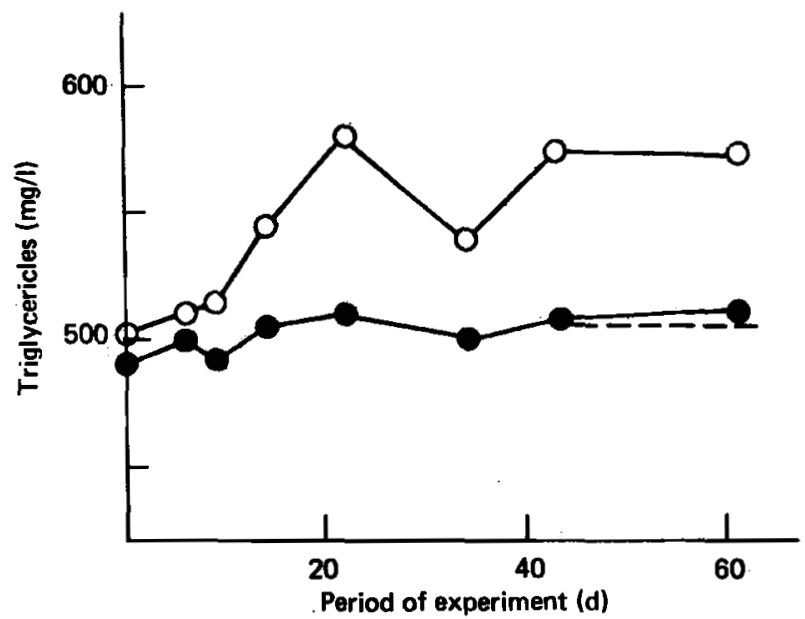

Fig. 1. Changes in serum triglycerides ( $\mathrm{mg} / \mathrm{l})$ in groups of four pigs fed on a low-magnesium diet $(\mathrm{O}-\mathrm{O})$ or a control diet $(--)$; $(--)$ reference level. For details of diet, see Table $\mathrm{I}$ and p. 54 .

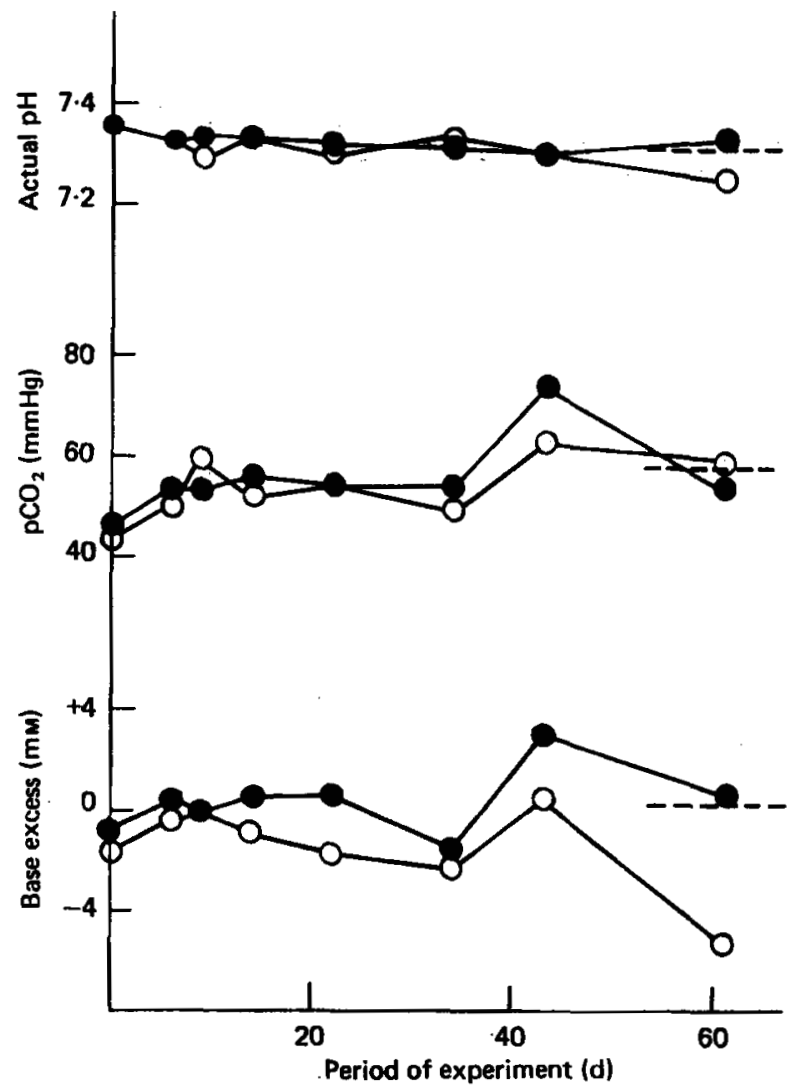

Fig. 2. Changes in blood actual $\mathrm{pH}$, partial pressure of carbon dioxide $\left(\mathrm{pCO}_{2} ; \mathrm{mmHg}^{2}\right.$ and base excess (mM) in groups of four pigs fed on a low-magnesium diet $(\mathrm{O}-\mathrm{O})$ or a control diet (-) ; (--) reference level. For details of diet, see Table I and p. 54. 


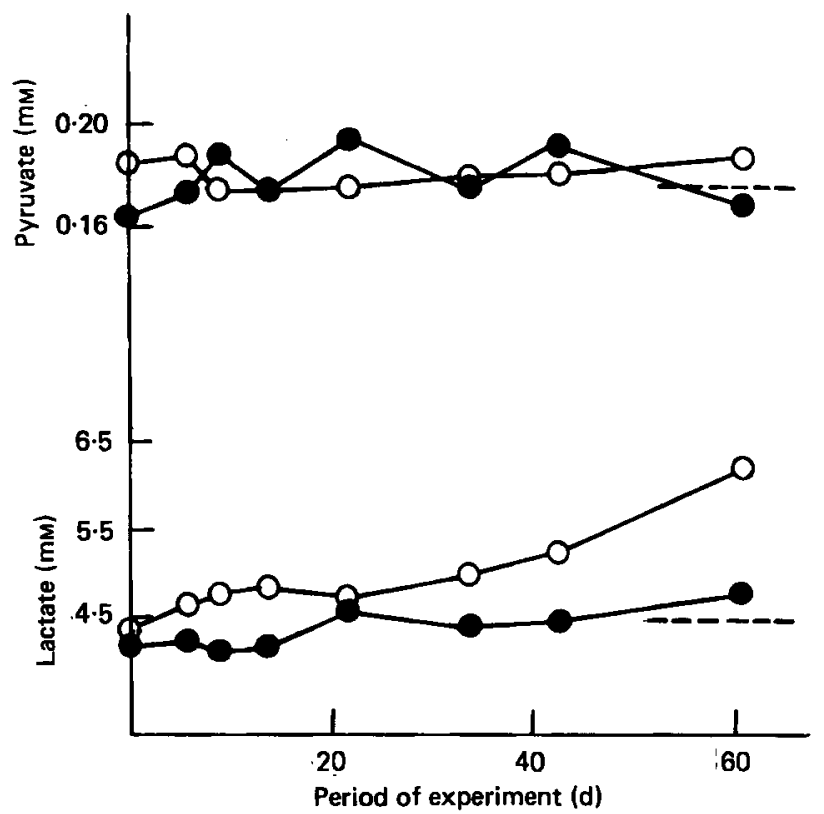

Fig. 3. Changes in blood lactate $(\mathrm{mM})$ and pyruvate $(\mathrm{mM})$ values in groups of four pigs fed on a low-magnesium diet $(\mathrm{O}-\mathrm{O})$ or a control diet $\left(\mathrm{O}_{-}\right) ;(--)$reference level. For details of diet, see Table I and p. 54 .

Table 3. Dependences between the various measurements within the groups according to the linear regression analysis carried out on days $14-6 \mathrm{I}$.

(Regression coefficients $(c)$ from estimated equations of type $y=a+b \times$ period of experiment $(d)+c x$ with their level of statistical significance are given)

\begin{tabular}{|c|c|c|c|c|c|c|}
\hline \multirow[b]{2}{*}{$\begin{array}{l}\text { Independent variable } \\
\text { Dependent variable }\end{array}$} & \multicolumn{3}{|c|}{ Control group } & \multicolumn{3}{|c|}{ Low-magnesium group } \\
\hline & Magnesium & Calcium & $\mathrm{Mg}: \mathrm{Ca}$ & Magnesium & Calcium & $\mathrm{Mg}: \mathrm{Ca}$ \\
\hline Blood pH & - & - & - & $0.29^{*}$ & - & $1.25^{* *}$ \\
\hline Serum glucose & - & - & - & $-11 \cdot 34^{* *}$ & - & - \\
\hline Serum inorganic phosphorus & $2 \cdot 20^{* * *}$ & - & $3.22 *$ & $\ldots$ & - & 一 \\
\hline ALAT & - & - & $96.07^{*}$ & - & - & - \\
\hline$\gamma-\mathbf{G T}$ & - & $-6 I \cdot 64 *$ & $303 \cdot 17^{*}$ & - & - & - \\
\hline Creatinine & $307.55^{*}$ & - & - & - & $73 \cdot 72^{*}$ & - \\
\hline Total serum protein & $113^{\circ} 40^{*}$ & - & - & - & - & - \\
\hline
\end{tabular}

ALAT, alanine aminotransferase; $\gamma$-GT, D-glutamyltransferase.

* $P<0.05$, "** $P<0.01$, *** $P<0.001$.

Astrup measurement, lactate and pyruvate are shown in Figs. I-3 and in Table 2 in which serum $\mathrm{Mg}$ and molar $\mathrm{Mg}: \mathrm{Ca}$ values are also given.

In the low-Mg group $\mathrm{pH}$ decreased with time (d) on days I4-6I. A statistically significant positive dependence between blood $\mathrm{pH}$ and molar $\mathrm{Mg}: \mathrm{Ca}$ in serum was also found as shown by the following estimated equation:

$\mathrm{pH}=6.98-0.0017 T+1.25 \mathrm{Mg}: \mathrm{Ca}(P<0.001, P<0.01)$. The equation represents $62.0 \%$ of the total variation of blood $\mathrm{pH}$. 
More information of dependences between various measurements is shown in Table 3 . All information originates from statistically significant equations. For example, in the low-Mg group a statistically significant positive dependence was found between blood $\mathrm{pH}$ and serum $\mathrm{Mg}$, and a negative one between serum glucose and $\mathrm{Mg}$.

Furthermore, in the control group a statistically significant positive dependence was found between ALAT activity and molar Mg: $\mathrm{Ca}$ in serum as well as between $\gamma$-GT and $\mathrm{Mg}: \mathrm{Ca}$. A negative dependence was found between $\gamma$-GT activity and serum $\mathrm{Ca}$.

In the low-Mg group, a statistically significant positive dependence was also found between body temperature and blood lactate content as shown by the following estimated equation:

$$
\text { body temperature }=38.49-0.00064 T+0.017 \text { *lactate content }\left({ }^{*} P<0.05\right) \text {. }
$$

No specific histopathological change was found in heart, liver or kidney of the experimental animals.

\section{DISCUSSION}

The $\mathrm{Mg}$ content of the experimental diet, $\mathrm{r} \cdot 0 \mathrm{~g} / \mathrm{kg}$, was approximately half that in ordinary pig food. This was achieved by replacing oat flour mainly by white wheat flour and by using dried blood as a protein source. Consequently, pigs were fed on a low-Mg diet instead of the so-called zero diet.

In both groups the phosphorus content of the food was abnormally low, and hence the Ca:P value relatively high $(\mathrm{I} \cdot 66)$. However, this seems not to have disturbed the course of the experiment, because the important factors indicating metabolic disturbances in the low-Mg group were maintained close to the reference levels in the control group.

The use of venous blood in the determination of the Astrup measurements causes an increase in $\mathrm{pCO}_{2}$ and a lowering in $\mathrm{pH}$ when compared with an ordinary determination from the arterial or capillary blood. Venous blood was used for practical reasons concerning sampling.

The maintenance of the triglyceride, base excess, standard bicarbonate and lactate values in the control group on the level of the reference values, and a statistically significant deviation from the control group values in all these measurements of the low-Mg group, indicate that the pigs of the low-Mg group very likely suffered from $\mathrm{Mg}$ deficiency. The minimum $\mathrm{Mg}$ content needed in the pig food according to the normal values recommended by the ARC (1966) and NRC (1968) seems, therefore, to be too low, as suggested by Nuoranne $(1971,1978 a, b)$.

In earlier studies both increases and no changes in neutral fat concentration have been found in Mg-deficient animals (see Seelig \& Heggtveit, 1974). A significant increase in triglycerides was found in the low-Mg group of the present work. The fat content of the experimental food was $17 \mathrm{~g} / \mathrm{kg}$ only, thus indicating that the increase in serum triglycerides does not need to depend on the amount or quality of food fat. As the growth of the experimental pigs was rather good, the possibility that the increase in triglycerides was due to the mobilization of body fat is also unlikely.

It seems possible that the increase in serum triglycerides was secondary to changes in carbohydrate metabolism. This is suggested by the rises in blood lactate as well as in the lactic acid/pyruvic acid value in the low-Mg group. A possible explanation for these changes and for the lowering of the base excess and standard bicarbonate values of the low-Mg group might be a disturbance in oxidative phosphorylation. In Mg-deficient Escherichia coli an increased production of lactate and a decrease in respiration were 
found (Günther \& Mariss, 1968). In bacteria, $\mathrm{Mg}$ deficiency causes an increase in phospholipids (Günther et al. I975).

Further studies are required to explain the mechanism by which the low-Mg diet induced the metabolic disturbances. Minor differences in serum $\mathrm{Mg}$ and $\mathrm{Mg}: \mathrm{Ca}$ values between the groups are in agreement with the earlier finding that serum $\mathrm{Mg}$ cannot be considered as a reliable index of body $\mathrm{Mg}$ status (Nuoranne, $1978 \mathrm{c}$ ).

The authors are grateful to Ms Ritva Perttilä, technical assistant, to Ms Esteri Väkiparta, dairymaid, to Mr Ilkka Linna, keeper of animals, to Mr Kalevi Heinonen, cand. med. vet., and to Mr Sauli Holmström, cand. med. vet., for housing the experimental animals and for technical assistance in taking samples. The skilful laboratory work of Ms Eila Saaranen, technician, Ms Pirjo Puroranta, technician and Mr Harry Lybeck, head of the department, is also acknowledged. The authors also thank Mr Juhani Tuominen, licentiate of political science, for statistical analysis.

This study was supported by the Research Foundation of Orion-yhtymä and by Suomen Kulttuurirahasto.

\section{REFERENCES}

Agricultural Research Council (1966). The Nutrient Requirements of Farm Livestock, No. 3, Pigs. London: H.M. Stationery Office.

Barka, T. \& Anderson, P. J. (1965). Histochemistry. New York: Hoeber Medical Division, Harper \& Row.

Czok, R. \& Lamprecht, W. (1974). In Methods of Enzymatic Analysis, 2nd ed. [H. U. Bergmeyer, editor]. New York and London: Academic Press.

Günther, T. \& Mariss, P. (1968). Hoppe-Seyler's Z. Physiol. Chem. 349, 623.

Günther, T., Richter, L. \& Schmalbeck, J. (1975). J. gen. Microbiol. 86, 19 I.

Gutman, I. \& Wahlefeld, A.W. (1974). In Methods of Enzymatic Analysis, 2nd ed. [H. U. Bergmeyer, editor]. New York and London: Academic Press.

Jacobson, D. R., Hemken, R. W., Button, F. S. \& Hatton, R. H. (1972). J. Dairy Sci. 55, 935.

National Research Council (1968). The Nutrient Requirements of Swine; publ. no. 1599. Washington, DC: National Research Council.

Nuoranne, P. (1971). Suomen EläinlääkLehti 77, 467.

Nuoranne, P. (1974). Suomen EläinlääkLehti 80, 258.

Nuoranne, P. (1978a). Nord. Vet.-Med. 30, 74.

Nuoranne, P. (1978b). Proc. 13th Nordic Vet. Congr., Turku, Finland.

Nuoranne, P. (1978c). Nord. Vet.-Med. 30, 71 .

Seelig, M. S. \& Heggtveit, H. A. (1974). Am. J. clin. Nutr. 27, 59.

Szelényi, I. (1973). Wld Rev. Nutr. Diet. 17, 189.

Wahlefeld, A. W. (1974). In Methods of Enzymatic Analysis, 2nd ed. [H. U. Bergmeyer, editor]. New York and London: Academic Press. 